\title{
Reconstitution and lipid requirements of porcine tissue thromboplastin
}

\author{
Citation for published version (APA):
}

Wijngaards, G., van Deenen, L. L. M., \& Hemker, H. C. (1977). Reconstitution and lipid requirements of porcine tissue thromboplastin. BBA - Lipids and Lipid Metabolism, 488(1), 161-171. https://doi.org/10.1016/0005-2760(77)90134-5

Document status and date:

Published: 20/07/1977

DOI:

10.1016/0005-2760(77)90134-5

Document Version:

Other version

\section{Please check the document version of this publication:}

- A submitted manuscript is the version of the article upon submission and before peer-review. There can be important differences between the submitted version and the official published version of record.

People interested in the research are advised to contact the author for the final version of the publication, or visit the DOI to the publisher's website.

- The final author version and the galley proof are versions of the publication after peer review.

- The final published version features the final layout of the paper including the volume, issue and page numbers.

Link to publication

\footnotetext{
General rights rights.

- You may freely distribute the URL identifying the publication in the public portal. please follow below link for the End User Agreement:

www.umlib.nl/taverne-license

Take down policy

If you believe that this document breaches copyright please contact us at:

repository@maastrichtuniversity.nl

providing details and we will investigate your claim.
}

Copyright and moral rights for the publications made accessible in the public portal are retained by the authors and/or other copyright owners and it is a condition of accessing publications that users recognise and abide by the legal requirements associated with these

- Users may download and print one copy of any publication from the public portal for the purpose of private study or research.

- You may not further distribute the material or use it for any profit-making activity or commercial gain

If the publication is distributed under the terms of Article $25 \mathrm{fa}$ of the Dutch Copyright Act, indicated by the "Taverne" license above, 
Biochimica et Biophysica Acta, 488 (1977) 161-171

(C) Elsevier/North-Holland Biomedical Press

BBA 57021

\section{RECONSTITUTION AND LIPID REQUIREMENTS OF PORCINE TISSUE THROMBOPLASTIN}

\section{G. WIJNGAARDS *, L.L. M. VAN DEENEN and H.C. HEMKER}

Laboratory of Biochemistry, University of Utrecht, University Centre "De Uithof",

Padualaan 8, Utrecht, Department of Biochemistry, State University Limburg,

Maastricht, and Gaubius Institute, Health Research Organization TNO,

Herenstraat $5 d$, Leiden (The Netherlands)

(Received December 22nd, 1976)

\section{Summary}

Active tissue thromboplastin can be separated into an inactive protein fraction and a lipid fraction. Recombination of these moieties results in an active thromboplastin. Most complete regeneration of the thromboplastin activity was obtained by a modified solubilization-dialysis procedure using taurocholate at $\mathrm{pH} 4.0$.

The protein moiety combined with pure phospholipids produced no thromboplastin activity, except for phosphatidylethanolamine which produced only low activity. Highly active preparations were obtained by relipidation of the protein moiety with binary phospholipid mixtures. Mixtures most effective in restoring the thromboplastin activity were phosphatidylethanolamine/phosphatidylserine $65 / 35(\mathrm{w} / \mathrm{w})$, phosphatidylcholine/phosphatidylserine $57 / 43(\mathrm{w} / \mathrm{w})$ and phosphatidylcholine/phosphatidylglycerol 48/52 (w/w).

Mixtures of alkylamine and phospholipid combined with the thromboplastin protein also regenerated the activity. Oleoylamine/phosphatidylserine $33 / 67(\mathrm{w} / \mathrm{w})$ and stearoylamine/phosphatidylglycerol 15/85 (w/w) were found to be optimum mixtures.

One characteristic feature for each optimum lipid mixture was an identical electrophoretic mobility. This consistent observation demonstrates that a particular charge of the lipid moiety is a requirement for optimum exhibition of the activity of the thromboplastin protein.

Lipids containing unsaturated fatty acids were found to be another requirement. Increased unsaturation in the fatty acids correlated with an increase in the thromboplastin activity of the recombinant. Complete saturation resulted in inactive preparations.

* Present address and to whom reprint requests should be addressed: Gaubius Institute, Health Research Organization TNO, Herenstraat $5 \mathrm{~d}$, Leiden, The Netherlands. 


\section{Introduction}

Lipids are important constituents of tissue thromboplastin preparations, as originally observed by Wooldridge [1]. He injected tissue extracts of various origins in animals and observed no lethal effect if the preparations were previously extracted with alcohol-ether. Mills [2] confirmed these findings with a purified thromboplastin preparation from beef lung and was able to regain most of the high clot-promoting activity by recombination of the less active lipid fraction with the inactive protein fraction.

Continued investigations showed that two procedures are suitable for the restoration of the clotting function starting with the lipid and protein fractions of tissue thromboplastin. In the first method, the lipid fraction is dissolved in an organic solvent such as pyridine [3], chloroform [4] or ethanol [5] and the dry protein fraction is added. After mixing, the solvent is evaporated and the residue suspended in saline or buffer. The second method consists of solubilization of the lipids in a buffered aqueous medium containing sodium deoxycholate, followed by the addition of protein. During dialysis against buffer, the detergent is removed and recombination takes place. The degree of restoration of thromboplastin activity is influenced by the $\mathrm{pH}$ and ionic strength of the buffer [6].

Substitution of the natural lipid mixture by various single natural and synthetic phospholipids was first performed by Kuhn and Klesse [7] to investigate the involvement of a specific phospholipid in the restoration of the thromboplastin activity. The results of their recombination experiments and those of some other investigations showed that natural phosphatidylethanolamines which contain both saturated and unsaturated fatty acids appear to be the most effective $[4,5,7,8]$, whereas phosphatidylethanolamines with only saturated fatty acids are not [7,8]. Inactive preparations were obtained after reassociation of the protein moiety with phosphatidylserine, phosphatidylinositol, phosphatidic acid and synthetic phosphatidylcholines; the results with biological species of phosphatidylcholine are not identical. Nevertheless, definite conclusions about the lipid requirements of the protein moiety of tissue thromboplastin can hardly be drawn.

In this communication, the $\mathrm{pH}$ dependence of the recombination is described, using taurocholate instead of deoxycholate. Recombination of the purified protein moiety of porcine lung thromboplastin with several defined phospholipid mixtures and phospholipid/alkylamine mixtures revealed important information about the lipid requirements of this clotting factor. An abstract of this study has been published [9].

\section{Materials and Methods}

Porcine lung thromboplastin (TP) was prepared from fresh lungs by differential centrifugation according to the method of Chargaff et al. [10] with some modifications [11].

Purified protein moiety of porcine lung thromboplastin was obtained after delipidation of the lyophilized thromboplastin with $n$-heptane/n-butanol 2/1 (v/v) followed by gel filtration of the solubilized protein fraction on Sephadex 
G-200 in the presence of $0.25 \%$ sodium deoxycholate [12].

Phospholipid mixture of porcine lung thromboplastin was isolated from the $n$-heptane/n-butanol extract of the thromboplastin. The extract was evaporated under reduced pressure and the residue was dissolved in chloroform. This solution was applied to a silicic acid column previously equilibrated with chloroform. Neutral lipids were eluted with chloroform/methanol mixtures containing 5\% and $10 \%(\mathrm{v} / \mathrm{v})$ methanol. This was followed by the elution of the phospholipids. For that purpose, the methanol concentration was gradually increased from $15 \%$ to $60 \%(\mathrm{v} / \mathrm{v})$. These fractions were combined and evaporated and the residue was dissolved in $n$-pentane. Traces of silicic acid were removed by the addition of $5 \%(\mathrm{v} / \mathrm{v})$ of water followed by centrifugation for $20 \mathrm{~min}$ at $2000 \times$ $g$ at room temperature. The supernatant was evaporated and the phospholipid mixture was dissolved in n-pentane, which had been dessicated over anhydrous sodium carbonate, and stored under nitrogen at $-20^{\circ} \mathrm{C}$.

Phospholipid suspension was prepared from the petroleum ether extract of acetone-dried human brain tissue. The extract was evaporated under reduced pressure and the lipids were dissolved in diethyl ether. This solution was added dropwise to a stirred veronal-acetate buffer through which nitrogen was bubbled. The suspension obtained was stored at $-20^{\circ} \mathrm{C}(11)$. This preparation served as the lipid surface for the formation of the prothrombin activating complex in the assay of thromboplastin activity.

Phosphatidic acid was kindly supplied by Dr. J. de Gier of the Laboratory of Biochemistry. It was prepared from egg yolk phosphatidylcholine by degradation with phospholipase $D$, which had been extracted from savoy cabbage according to Davidson and Long [13].

Phosphatidylcholine was isolated from egg yolk according to Singleton et al. [14]. This was followed by chromatography on aluminium oxide using the stepwise elution method of Renkonen [15] with an increased methanol concentration $(50 \%)$ to elute phosphatidylcholine. After evaporation under reduced pressure, the phosphatidylcholine fraction was dissolved in n-pentane. Water $(5 \%)(\mathrm{v} / \mathrm{v})$ was added to moisten traces of aluminium oxide which were sedimented subsequently by centrifugation at $2000 \times g$ for $20 \mathrm{~min}$. The supernatant was evaporated and the phospholipid preparation dissolved in n-pentane which had been dried over anhydrous sodium carbonate. The solution was stored in ampoules at $-20^{\circ} \mathrm{C}$ under nitrogen.

Degradation of the phosphatidylcholine preparation, in particular, could be detected in an early stage from the electrophoretic mobility measurements. In that case, the chromatography on aluminium oxide was repeated or a new preparation was started.

Phosphatidylethanolamine was purified from the crude egg yolk phospholipids obtained by the method of Singleton et al. [14]. This preparation was applied to a silicic acid column equilibrated with chloroform. Elution was performed with chloroform/methanol mixtures with increasing methanol concentration. Phosphatidylethanolamine was recovered at 15\% methanol. This preparation was further purified on DEAE-cellulose using "elution sequence 3 " as described by Rouser et al. [16], resulting in a phosphatidylethanolamine preparation which showed one single spot on silica gel thin layer chromatography. This preparation was dried under reduced pressure, dis- 
solved in dry $n$-pentane and stored in ampoules at $-20^{\circ} \mathrm{C}$ under nitrogen.

Synthetic dipalmitoyl phosphatidylethanolamine and dioleoyl phosphatidylethanolamine were obtained as generous gifts from Dr. J.D. Billimoria, Westminster School of Medicine, Biochemical Research Laboratory, London, England.

Phosphatidylglycerol was prepared from egg yolk phosphatidylcholine according to the method of Lennarz et al. [17]. This procedure was performed by Dr. H.M. Verheij of the Laboratory of Biochemistry.

Phosphatidylserine was purified from porcine brain tissue using the method of Sanders [18]. Hydrogenated phosphatidylserine was made from the natural preparation by passing hydrogen through a solution of phosphatidylserine in $n$-heptane in the presence of activated palladium for $5 \mathrm{~h}$ at room temperature. The hydrogenated phosphatidylserine was stored in chloroform at $-20^{\circ} \mathrm{C}$.

Recombination of the purified protein moiety and phospholipid was performed by the solubilization-dialysis procedure. An aliquot of the phospholipid stock solution corresponding to $1.0 \mathrm{mg}$ phospholipid was dried under vacuum and solubilized in $0.3 \mathrm{ml}$ veronal/chloride buffer $(I 0.015, \mathrm{pH} 7.35)$ containing sodium taurocholate $(\mathbf{1 . 3 \%})$. A protein preparation containing 0.7 $\mathrm{mg}$ protein was added and the volume was adjusted to $1.0 \mathrm{ml}$ with buffer. Removal of the taurocholate was achieved by dialysis for 65 to $70 \mathrm{~h}$ at $4^{\circ} \mathrm{C}$ against 6 changes of buffer. Sodium acetate/acetic acid buffers $(0.01 \mathrm{M})$ were used during dialyzing from $\mathrm{pH} 3.0$ to 6.0 ; in the $\mathrm{pH}$ region 6 to 8.5 , sodium 5,5-diethyl-barbiturate $(0.01 \mathrm{M})$ adjusted with hydrochloric acid was used.

For recombination with mixtures of phospholipids the constituent phospholipids were mixed in the desired proportions in chloroform solution. After evaporation of the solvent under vacuum, the residue was solubilized and recombined with the protein as above.

Thromboplastin activity of the recombinants was estimated by the twostage assay described earlier [11]. The first stage involved an incubation of purified human factor VII with the sample in the presence of calcium chloride. The degree of activation of factor VII was subsequently determined in a clotting system consisting of artificially depleted factor VII reagent, the phospholipid suspension and calcium chloride. The degree of activation was found to be directly proportional to the thromboplastin activity of the sample.

The activity was calculated from the clotting time with the aid of a standard curve and it was expressed in percent activity with reference to an equal amount of standard recombinant. The standard curve was plotted from the clotting times of a series of dilutions of an arbitrarily chosen preparation obtained by the recombination of the natural thromboplastin phospholipid mixture with delipidated thromboplastin at $\mathrm{pH}$ 4.0. The rectilinear relationship between the clotting time and $1 /([$ thromboplastin] $+\mathrm{L})$ also held for the recombinant activity [12]. Phospholipids were inactive in this assay system, indicating its specificity for tissue thromboplastin activity.

Prothrombinase formation. The capacity of the lipid of a recombinant to function as the lipid surface in prothrombinase formation can be determined by using Russell Viper Venom for rapid activation of factors $\mathrm{X}$ and $\mathrm{V}$. This test was performed in the presence of the phospholipid suspension in order to determine whether there was a possible influence of the lipid of the recom- 
binant on the prothrombinase formation in the assay of thromboplastin activity. A mixture of $0.1 \mathrm{ml}$ factor VII reagent, $0.1 \mathrm{ml}$ phospholipid suspension with optimal concentration and $0.1 \mathrm{ml}$ recombinant (diluted 1 to 3 with buffer) was incubated for $30 \mathrm{~s}$ at $37^{\circ} \mathrm{C}$. Thereafter, $0.1 \mathrm{ml}$ Russell Viper Venom $(0.1 \mathrm{mg} /$ $100 \mathrm{ml}$ ) in $0.033 \mathrm{M}$ calcium chloride was added and the clotting time determined.

In a number of samples of a defined experiment involving recombinants with a particular combination of phospholipids, the sample with the shortest clotting time, exhibiting optimal prothrombinase activity, was therefore taken as $100 \%$. Using dilutions of this recombinant in the test system resulted in clotting times which showed a rectilinear graph when plotted on double logarithmic paper against the amount of the recombinant. Using this, the prothrombinase formation by other samples in the experiment can be expressed as a percentage of the activity with regard to the optimal phospholipid suspension/ recombinant mixture.

Protein was estimated by the method of Lowry et al. [19].

Phosphorus was determined according to the procedure described by Rouser et al. [20].

Taurocholate was measured as the absorbance in $65 \%$ sulphuric acid at 320 $\mathrm{nm}$.

Electrophoretic mobility $(\mu)$ of phospholipid particles was measured with the microelectrophoresis apparatus described by Bangham et al. (21). A $1.0 \mathrm{mg}$ amount of phospholipid was taken from the stock solution or from the stock solutions in case of mixtures and the solvent was evaporated under vacuum. The residue was suspended by hand-shaking in $5.0 \mathrm{ml}$ veronal/chloride buffer ( $I 0.015, \mathrm{pH} 7.35$ ) with the addition of 1 or 2 glass beads. The mobility was expressed as $\mathrm{cm}^{2} \cdot \mathrm{s}^{-1} \cdot \mathrm{V}^{-1}$.

\section{Results}

\section{Determination of $\mathrm{pH}$ optimum for recombination}

The application of taurocholate for "solubilization" of the lipid in the recombination procedure for the lipid and protein moiety of thromboplastin was found to be very suitable. It did not inactivate the protein and it could be removed quite reasonably by dialysis (Table I). The dialysis time for removal of the detergent from a recombinant was shorter than that for the phospholipid alone. This is possibly the result of the competitive association of lipid and protein. In the succeeding recombination experiments, a dialysis time of 65 to 70 hours was employed in order to be sure that no residual taurocholate, which could lead to false results concerning the lipid requirements of the protein, was present.

Taurocholate has the advantage of being soluble over a wide $\mathrm{pH}$ range. Therefore, we were able to demonstrate that recombination of the phospholipid mixture of thromboplastin and its protein moiety produced the highest clotting activity if the detergent was removed by dialysis at $\mathrm{pH} 4.0$. This result indicates that, for optimal restoration, the conditions must be favourable from an electrostacic point of view.

Mixing of a suspension of the phospholipid mixture and the protein moiety 
TABLE I

REMOVAL OF SODIUM TAUROCHOLATE FROM DIFFERENT SOLUTIONS BY DIALYSIS AGAINST 0.01 M ACETATE BUFFER, pH 4.0.

\begin{tabular}{rccc}
\hline $\begin{array}{l}\text { Dialysis time } \\
\text { (h) }\end{array}$ & \multicolumn{3}{l}{ Sodium taurocholate removed $(\%)$} \\
\cline { 2 - 4 } & Only solvent & $\begin{array}{l}\text { Phospholipid } \\
(1 \%)\end{array}$ & Phospholipid (1\%)+ protein $(0.7 \%)$ \\
\hline 0 & 0 & 0 & \\
16 & 95.2 & 91.2 & 0 \\
24 & 97.8 & 93.6 & 91.0 \\
40 & 100 & 99.0 & 100 \\
48 & - & 99.0 & - \\
68 & - & 99.5 & - \\
92 & - & 99.6 & - \\
116 & - & 99.9 & - \\
140 & - & 100 & - \\
\hline
\end{tabular}

also produced a lipid · protein complex at $\mathrm{pH} 4.0$, but this complex showed no thromboplastin activity. This demonstrates that the solubilization-dialysis procedure is essential to regain the thromboplastin activity.

Recombination of the protein moiety and phospholipids, alkylamines, or their mixtures

Pure phospholipids were found to be rather ineffective in the restoration of the thromboplastin activity of the protein moiety. Thus, the recombinants with phosphatidic acid, phosphatidylcholine, phosphatidylglycerol and phosphatidylserine did not display thromboplastin activity, in spite of the fact that recombination had occurred. The recombinant with phosphatidylethanolamine was active but the activity was rather low (10 to $15 \%)$ when compared with the activity of the standard recombinant.

However, considerably higher activity of the recombinant was found if phosphatidylethanolamine was mixed with phosphatidylserine (Fig. 1). Especially phosphatidylethanolamine/phosphatidylserine $65 / 35$ (w/w) was very active. No special differences in the extent of dispersion of the various recombinants were observed by using the optical system of the microelectrophoresis apparatus. Comparable results were obtained with mixtures of phosphatidylcholine and phosphatidylserine (Fig. 1). The optimal activities of both types of mixtures were markedly higher than the activity obtained with the phospholipid mixture of thromboplastin. By the addition of phosphatidylserine to the phospholipid mixture, the activity of the recombinant could be increased and it was optimum at $22 \%$ phosphatidylserine (Fig. 1).

The data for the electrophoretic mobilities of the different phospholipids and phospholipid mixtures in Fig. 1 showed that maximum activity always was obtained at a particular charge of the lipid. Maximum activity coincided with mixtures which had an electrophoretic mobility of $-7.00,-7.15$ and -6.95 . $10^{-4} \mathrm{~cm}^{2} \cdot \mathrm{s}^{-1} \cdot \mathrm{V}^{-1}$ in $0.015 \mathrm{M}$ veronal/chloride buffer, $\mathrm{pH} 7.35$ (Fig. 1). Additional proof was obtained with mixtures of phosphatidylcholine and phosphatidylglycerol and phosphatidylglycerol and stearoylamine. The electrophoretic mobilities of phosphatidylcholine/phosphatidylglycerol 48/52 (w/w) 

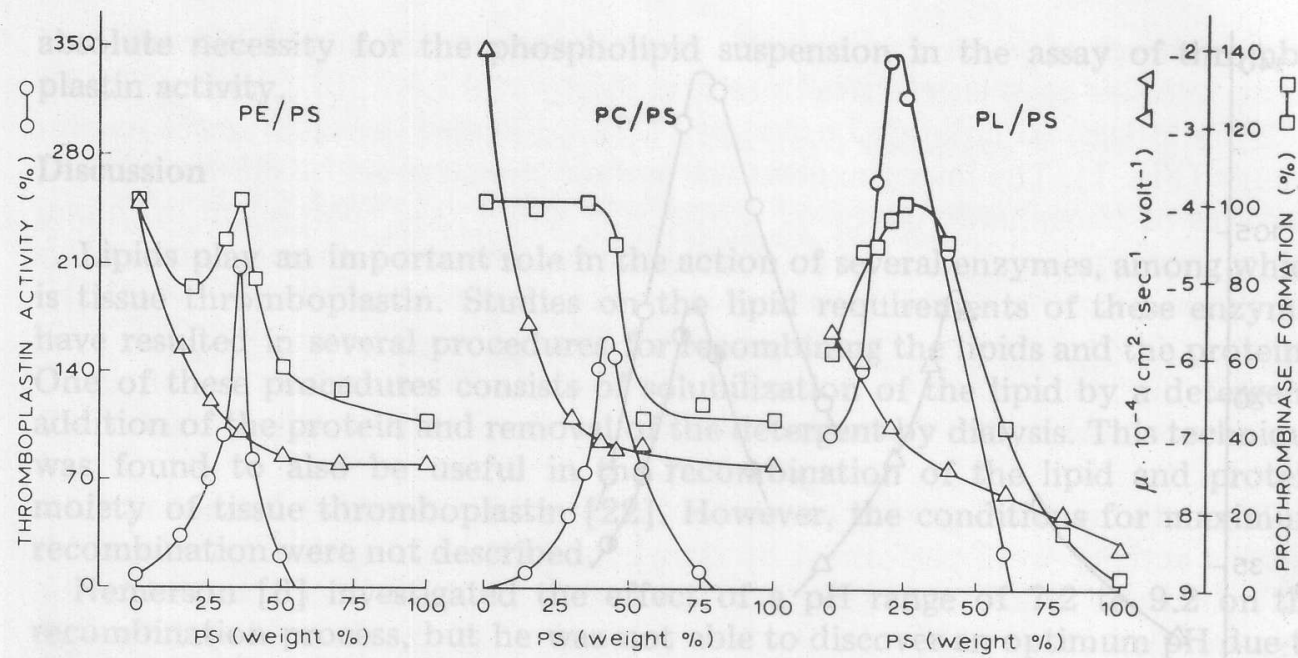

Fig. 1. Influence of phospholipid composition upon the activity of the recombinant. Relipidation of purified protein moiety of porcine lung thromboplastin with egg phosphatidylethanolamine/brain phosphatidylserine mixtures (PE/PS), with egg phosphatidylcholine/brain phosphatidylserine mixtures (PC/PS) or with the thromboplastin phospholipid mixture enriched with brain phosphatidylserine (PL/PS) at pH 4.0. The thromboplastin activity of the recombinants is expressed in percent activity with reference to the same amount of recombinant containing the thromboplastin phospholipid mixture. The electrophoretic mobility $(\mu)$ of the phospholipid mixtures was measured in $0.015 \mathrm{M}$ veronal/chloride buffer. $\mathrm{pH}$ 7.35. The prothrombinase formation was measured as indicated in the text.

and phosphatidylglycerol/stearoylamine $85 / 15(\mathrm{w} / \mathrm{w})$ corresponding with maximum activities were -7.15 and $-7.00 \cdot 10^{-4} \mathrm{~cm}^{2} \cdot \mathrm{s}^{-1} \cdot \mathrm{V}^{-1}$, respectively [12].

Besides the influence of the surface charge of the lipid on the thromboplastin activity of the recombinant, the variation in the degree of saturation of the fatty acid chains was investigated in some mixtures. There was a marked difference between the activity of recombinants with mixtures of dioleoyl phosphatidylethanolamine and brain phosphatidylserine and those of dipalmitoyl phosphatidylethanolamine and hydrogenated brain phosphatidylserine. In the preparations containing saturated fatty acids, no thromboplastin activity could be elicited (Fig. 2). The importance of unsaturated chains was confirmed by using mixtures of an alkylamine and phosphatidylserine with a more gradual increase in degree of saturation (Fig. 2).

The observed curves representing the thromboplastin activity of the recombinants in Fig. 1 and 2 might be due, however, to selective binding of certain phospholipid mixtures to the protein moiety. At the same time, the recombinant lipid mixture could have an effect on the prothrombinase formation in the thromboplastin assay in spite of the addition of the phospholipid suspension. This would be expressed in the clotting times and consequently in the thromboplastin activities of the recombinants. Control experiments were therefore performed on the recombinant preparations to verify the observed phenomenon. The $\mathrm{pH}$ of the recombinant preparations was adjusted to 7.5 to exclude electrostatic interactions between the lipid and protein. The preparation was then subjected to centrifugation under different conditions. Determination of the protein content in the supernatant after centrifugation for $2 \mathrm{~h}$ 


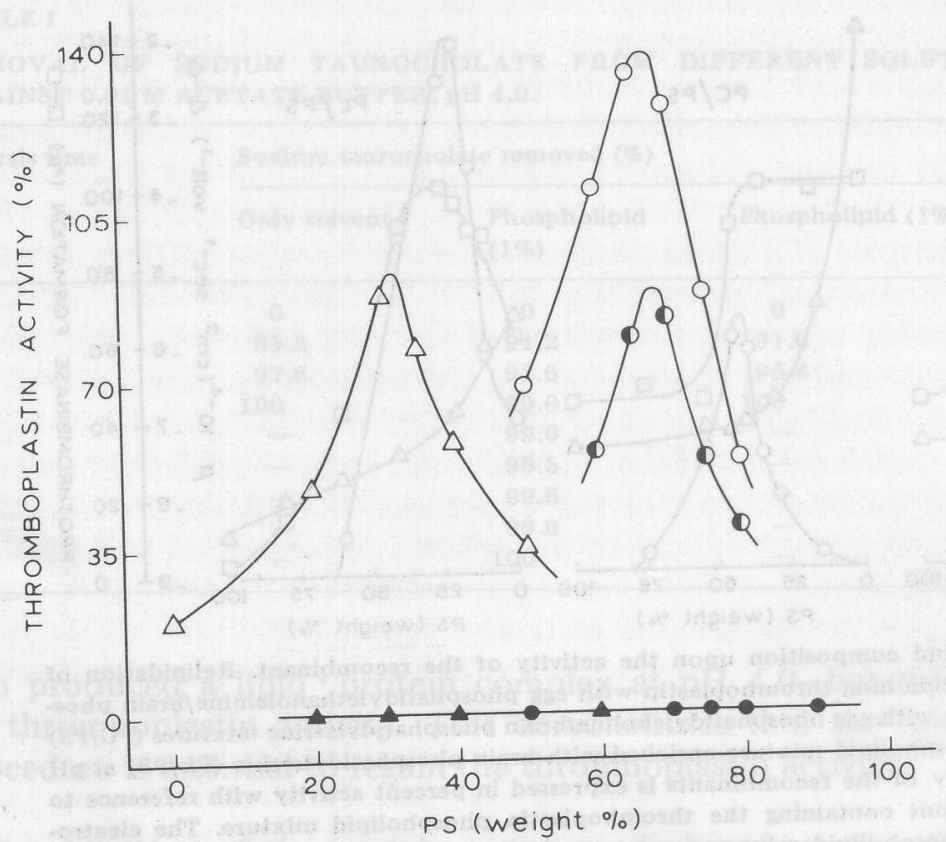

2. Influence of the degree of saturation of the lipid moiety on the thromboplastin activity of the recombinant. Relipidation of purified protein moiety of thromboplastin with dioleoyl phosphatidylethanolamine/brain phosphatidylserine mixtures $(\Delta)$, with dipalmitoyl phosphatidylethanolamine/hydrogenated brain phosphatidylserine mixtures $(\Delta)$, with oleoylamine/brain phosphatidylserine mixtures $(0)$, with stearoylamine/brain phosphatidylserine mixtures (c) or with stearoylamine/hydrogenated brain phosphatidylserine mixtures $(\bullet)$ at pH 4.0. Further details as in Fig. 1.

at $37000 \times g$ revealed that 95 to $99 \%$ of the protein was sedimented in all recombinants. A similar centrifugation after increase in the density of the suspensions to 1.08 by an equal volume of $38 \%$ sucrose solution, followed by a phosphorus assay of the supernatant, demonstrated that 95 to $100 \%$ of the phospholipid was present in the pellet, whereas phospholipid alone did not sediment. So, there was no selective binding of certain phospholipid mixtures to the protein moiety; in all recombinants, both the phospholipid and the protein moieties were completely associated with each other.

The effect of the recombinant on the prothrombinase formation in the assay of its thromboplastin activity was studied in a test system in which the variable activation of factor $\mathrm{X}$ by mixtures of factor VII and the different recombinants was substituted by a constant amount of Russell Viper Venom. These results showed that the clotting of factor VII reagent in the presence of the phospholipid suspension was slightly affected by the type of recombinant present (Fig. 1: PE/PS and PC/PS recombinants). Elimination of the phospholipid suspension from this test demonstrated that the lipid moiety of particular recombinants did not adequately serve as the lipid surface of the prothrombinase (Fig. 1: PL/PS recombinants). These observations demonstrate that, in the assay of the thromboplastin activity of the recombinants, the phospholipid suspension almost completely accomplished its expected role in the formation of the prothrombin activating complex. Furthermore, this proves the 
absolute necessity for the phospholipid suspension in the assay of thromboplastin activity.

\section{Discussion}

Lipids play an important role in the action of several enzymes, among which is tissue thromboplastin. Studies on the lipid requirements of these enzymes have resulted in several procedures for recombining the lipids and the proteins. One of these procedures consists of solubilization of the lipid by a detergent, addition of the protein and removal of the detergent by dialysis. This technique was found to also be useful in the recombination of the lipid and protein moiety of tissue thromboplastin [22]. However, the conditions for maximum recombination were not described.

Nemerson [6] investigated the effect of a pH range of 7.2 to 9.2 on the recombination process, but he was not able to discover an optimum $\mathrm{pH}$ due to the insolubility of the deoxycholic acid at lower $\mathrm{pH}$ values. He effected an improvement of the relipidation by the addition of sodium chloride. This observation and the favourable effect of salts on the recombination of lipids and protein in other studies suggest a neutralizing action of cations on the negatively charged groups of the lipid and protein which interfere with the reconstitution by electrostatic repulsion. This view was supported by recombination of a phospholipid mixture and the protein moiety of thromboplastin at $\mathrm{pH} 7.5$ in the presence of cations with low and high affinities for lipid surfaces $\left(\mathrm{Na}^{+}\right.$and $\left.\mathrm{Mg}^{2+}\right)$ [12].

The elimination of the electrostatic repulsion by the added salt could also be achieved by lowering the $\mathrm{pH}$. The subsequent solubility problem of deoxycholic acid could be surmounted by using taurocholate. By this modification, we showed that maximum restoration of the thromboplastin activity is obtained if the $\mathrm{pH}$ of the dialysis buffer is 4.0 . The activity of the recombinant at $\mathrm{pH} 4.0$ was always higher than for recombinants prepared at $\mathrm{pH} 7.5$ in the presence of optimum concentration of sodium chloride $(0.35 \mathrm{M})$ or manganese chloride $(0.01 \mathrm{M})$.

Substitution of the thromboplastin phospholipid mixture by phosphatidic acid, phosphatidylcholine, phosphatidylglycerol and phosphatidylserine resulted in inactive recombinants, while some activity was found in the phosphatidylethanolamine recombinant. The observations with phosphatidylcholine and phosphatidylethanolamine are not identical with those of the majority of the previous studies $[5,7,8]$. This contradiction can be due to the use of impure phospholipid preparations because of the previous lack of convenient purification methods or unnoticed degradation of the lipids during storage. An increased negative charge of the phosphatidylcholine and phosphatidylethanolamine micelles is a usual consequence due to the presence of the cleaved, negatively charged fatty acids in the micelles.

Investigations with mixtures of phospholipids revealed that the charge of the lipid moiety is very critical in the restoration of the procoagulant property of the protein moiety. The negative charge of pure phospholipids is too low (phosphatidylethanolamine and phosphatidylcholine) (Fig. 1) or too high (phosphatidylserine, phosphatidic acid and phosphatidylglycerol) (Fig. 1) (12), 
but the charge of particular mixtures reaches the correct value. Lipid mixtures whose micelles have an electrophoretic mobility of $-7.05 \cdot 10^{-4} \mathrm{~cm}^{2} \cdot \mathrm{s}^{-1} \cdot \mathrm{V}^{-1}$ in $0.015 \mathrm{M}$ veronal/chloride buffer, $\mathrm{pH} 7.35$, produced the most active recombinants (Fig. 1). The importance of the surface charge could be illustrated with mixtures of phosphatidylglycerol, a relatively minor lipid component in animal tissues, and the nonphysiological stearoylamine. The mixture phosphatidylglycerol/stearoylamine $85 / 15(\mathrm{w} / \mathrm{w})$ which had the above mobility restored the activity of the protein. The function of this particular charge of the lipid moiety may be connected with the binding of calcium which could, in its turn, be critical in the formation of the thromboplastin - calcium - factor VII complex.

Other studies dealing with a relation between the charge of lipids and their clotting activity were performed by Bangham [23] and Papahadjopoulos et al. [24]. In these studies, an effect of the charge of lipids was observed in the Stypven time test [23] and in the activation of prothrombin [24]. Our investigations on the capacity of the recombinants to act in prothrombinase formation are related to the same step in the clotting mechanism and they confirm the previous results.

Investigations into the separation of tissue thromboplastin preparations into their lipid and protein fractions showed the existence of hydrophobic interactions between both moieties. Fatty acid chains of the lipids are involved in this type of interaction. Changes in the degree of saturation of these chains markedly influenced the activity of the recombinant (Fig. 2). Lipids containing only saturated fatty acids produced completely inactive recombinants. This demonstrates that, besides the charge of the lipid, the physicochemical condition of the hydrophobic part should meet certain conditions which are important for the activity of the recombinant. In this respect, the lower rigidity of the unsaturated fatty acid chains of the lipid, the closer location of methyl groups of these fatty acid chains to the polar region of the membrane and the greater cross-sectional area of the phospholipids may be important points with relation to certain required interaction of the hydrophobic moieties between the lipid and the protein.

\section{References}

1 Wooldridge, L.C. (1893) On the Chemistry of the Blood and other Scientific Papers, Kegan Paul, Trüibner and Co., London, England

2 Mills, C.A. (1921) J. Biol. Chem. 46, 135-165

3 Deutsch, E., Irsigler, K. and Lomoschitz, H. (1964) Thromb. Diath. Haemorrh. 12, 12-34

4 Hecht, E. and Wijngaards, G. (1969) Thromb. Diath. Haemorrh. 21, 546-560

5 Liu, D.T.H. and McCoy, L.E. (1975) Thromb. Res. 7, 213-221

6 Nemerson, Y. (1969) J. Clin. Invest. 48, 322-331

and Klesse, P. (1957) Naturwissenschaften 44 II, 352-353

8 Nemerson, Y. (1968) J. Clin. Invest. $47,72-80$

1Vth International Congress on Thrombosis and Haemostasis, Vienna, Austria, Abstract 208

10 Chargaff, E., Moore, D.H. and Bendich, A. (1942) J. Biol. Chem. 145, 593-603

11 Wijngaards, G. and Hemker, H.C. (1977) Haemostasis 6, 89--97

12 Wijngaards, G. (1972) Investigations on the Purification and Lipid Requirements of Tissue Thromboplastin, Thesis, Utrecht, The Netherlands

13 Davidson, F.M. and Long, C. (1958) Biochem. J. 69, 458-466 (1965) J. Am. Oil Chem. Soc. 42, 53-56

14 Singleton, W.S. Gray, M.S. 
15 Renkonen, O. (1962) J. Lipid Res. 3, 181-183

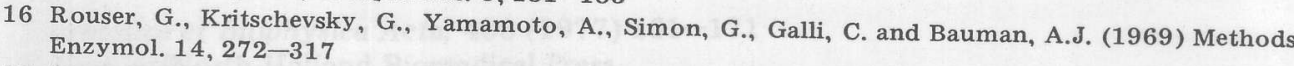

17 Lennarz, W.J., Bonsen, P.P.M. and Van Deenen, L.L.M. (1967) Biochemistry 6, 2307-2312

18 Sanders, H. (1967) Biochim. Biophys. Acta 144, 485-487

19 Lowry, O.H., Rosebrough, N.J., Farr, A.L. and Randall, R.J. (1951) J. Biol. Chem. 193, 265-275

20 Rouser, G., Fleischer, S. and Yamamoto, A. (1970) Lipids 5, 494-496

21 Bangham, A.D., Heard, D.H., Flemans, R. and Seaman, G.V.F. (1958) Nature 182, 642-644

22 Hvatum, M. and Prydz, H. (1966) Biochim. Biophys. Acta 130, 92-101

23 Bangham, A.D. (1961) Nature 192, 1197-1198

24 Papahadjopoulos, D., Hougie, C. and Hanahan, D.J. (1962) Proc. Soc. Exp. Biol. Med. 111, 412-416 